\title{
The Use of ICT in a Local Government Unit
}

\section{Małgorzata Nycz Wrocław University of Economics, Wrocław, Poland}

\section{malgorzata.nycz@ue.wroc.pl}

\author{
Zdzisław Pólkowski \\ Lower Silesian University of \\ Entrepreneurship and \\ Technology, Polkowice, Poland
}

\begin{abstract}
The focus of the paper is information and communications technology (ICT) solutions in hybrid information systems in a local government unit. As the exemplary local government unit, the social welfare center (Ośrodek Pomocy Społecznej, or "OPS") in Polkowice, Poland, was chosen. After a brief introduction, the problem statement, goal of study, research questions and methodology, and the issue of how ICT supports managers in the decision-making process are presented. The policy regarding ICT plays a crucial role in developing new tools; therefore, the section titled "ICT policy regarding to local government units" is devoted to this. Reasons why ICT solutions in local government units are not fully integrated are discussed. The model of a fully integrated system for local government units is next discussed, followed by a short conclusion.
\end{abstract}

Keywords: information and communications technology (ICT), local government units, hybrid systems, business processes, cloud computing

\section{Introduction}

Knowledge is becoming one of the most valuable resources. Since the 1980 s, we have been living in times characterized by rapid acceleration of civilization, which manifests itself, inter alia, in disseminating the use of IT not only in business practice, but also in public institutions. Countries with efficient ICT programs are able to curb the level of corruption and promote good governance (Brussel, 2011) and reduce some aspects of social exclusion (Zenebe Beyene and \& Abdissa Zerai, 2014). Many public institutions have introduced so-called e-government programs that incorporate ICT and use it to transform several dimensions of their operations, to create more accessible, transparent, effective and accountable government (Ali M. Al-Khouri, 2011). Appropriate knowledge has to be possessed to be able to recognise or foresee changes occurring in the environment or citizen requirements from local government units, and to quickly react to these changes.

Material published as part of this publication, either on-line or in print, is copyrighted by the Informing Science Institute. Permission to make digital or paper copy of part or all of these works for personal or classroom use is granted without fee provided that the copies are not made or distributed for profit or commercial advantage AND that copies 1) bear this notice in full and 2) give the full citation on the first page. It is permissible to abstract these works so long as credit is given. To copy in all other cases or to republish or to post on a server or to redistribute to lists requires specific permission and payment of a fee. Contact Publisher@InformingScience.org to request redistribution permission.

\section{Problem Statement}

Today, public institutions in Poland operate similarly to commercial companies. They face unprecedented pressure to improve service quality while progressively lowering their costs. At the same time, they are expected to become more accountable, transparent, customer focused and responsive to stakeholder 
needs. In a climate of shrinking budgets and resources, government institutions are tasked with more than simply reducing costs and increasing service levels. They face increased scrutiny from legislators, executives and other institutions (e.g. Inspector General for the Protection of Personal Data - GIODO). This brings about the need to increase transparency, accountability, and performance, as well as solve operational challenges, improve customer service, maximize resources and eliminate fraud, abuse and waste (MAIA Intelligence, 2014).

Today, IT systems in local government units are incapable of supporting longitudinal manager performance data analysis and reporting. The data are stored in multiple operational tables, preventing efficient integration and aggregation on demand. Authorities and IT specialists are looking for IT tools to support the decision-making process.

An analysis of the information system (IS) in the social welfare center in Polkowice shows that the system is dispersed and non-fully integrated. The following incompatible systems (modules) are used: SIGID, Pomost, Maintenance Benefits (Swiadczenia alimentacyjne), Family Benefits (Swiadczenia Rodzinne), Payer (Płatnik), Electronic Transmission (Przekaz elektroniczny), Bestia, Pefron, e-Delaracje and Doskomp.

The applied systems (modules) are based on the same of software and hardware platforms. Some are obsolete, non-scaled and inflexible. Separate, non-integrated applications are unable to meet the needs of users in terms of flexibility, orientation on business processes, usability, personalization, maintenance and optimization of management of costs related to IS.

Increasingly, in local government units, there are new needs for integration with online solutions and availability of business intelligence solutions in the hybrid information system. The latest generation of ERP (Enterprise Resource Planning) systems offers a combination of all these functionalities while remaining flexible solutions, easy to use and requiring less capital investment compared with older systems (Nycz \& Pólkowski, 2014a, 2014b).

This results in employees repeatedly enter the same data in different organizational units and in several independent databases, meaning there are no relations between them (Nycz \& Pólkowski, 2014a, 2014b).

A similar situation exists in other government units in Poland. This is due to the fact that some solutions are imposed by the ministry of social policy. On one hand, it affects standardization, on the other, it limits the managers in implementation of innovative changes. Despite this, managers in Polkowice are aware of the need for innovative changes. Moreover, whenever possible, they try to improve the situation. This paper proves the openness of the decision-makers in Polkowice to changes and innovation.

It is worth noting that in Polkowice, authorities treat the matter of computerization seriously, as evidenced in the common community board meetings, directors of local governments and academic institutions.

\section{Goal of the Study}

The problem described above definitely leads to a considerable need of research in this area. Since the process of implementation of new ICT solutions has already started, the authors decided to check the ICT systems dedicated for local government units in Poland. The goal of this study is to critically examine ICT solutions in a local government unit and to determine the applicability of ICT technology. The aim is to shed light on how the local government unit is approaching the ICT space, what this suggests for the future of ICTs in Poland and what it may tell us about the potential or actual role of ICTs in improving decision-making processes. This research was conducted as part of a larger study on the role of ICTs in selected institutions and companies in Polkowice, Poland. The Polkowice Commune is located in the north of the Lower Silesia Region, 
in an industrial area referred to as "The Copper Basin", which is also the economic motor of Lower Silesia (Powiat Polkowicki, 2014).

In the current development of the ICT systems context, deepened by the economic situation, managers and authorities, in order to improve operational efficiency, must look to the past for needed reports on previous and current situations (Fig. 1). The general goal is to make informed forecasts about future ICT systems in order to optimize resource allocation and consumption, and also to avoid possible problems that could have a negative impact on development of e-health systems. Managers and IT specialists also use forecasting to extrapolate how trends will change in coming years or as a benchmark for a long-term perspective of IT systems (Banica L., Pirvu D., Hagiu A., 2012).

IT providers, interacting with these requests, have launched various systems and tools to support managers in making better decisions, such as business intelligence platforms, forecasting software and DSS systems. In this paper, we discuss the capabilities of forecasting ICT systems and will highlight the advantages of using this kind of tool to improve services for clients. The services characterized above definitely lead to considerable changes in any ICT systems (Fig. 1).

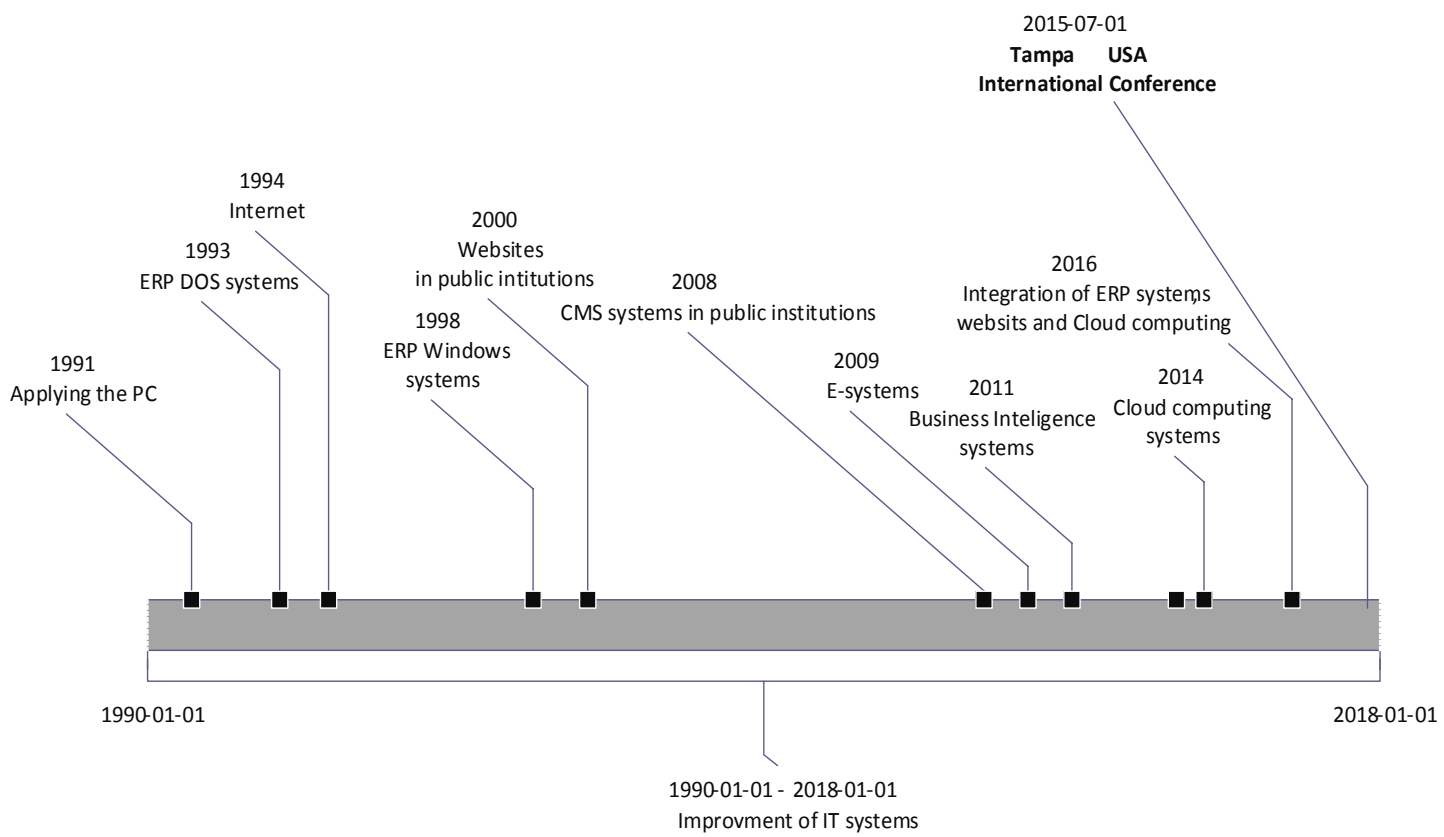

Figure 1. Past, current and future of the ICT systems in local government units in Poland (these dates should be treated with caution; Nycz, Pólkowski 2014)

Figure 1 shows there is a great amount of information on how processes of computer systems are being implemented, what data the services include and the capacity of the equipment as well as the software, human resources and the knowledge in this sphere. For this reason, it is highly likely that in the future there will be integration of information systems working in both the private and public cloud computer with internet systems.

\section{Research Questions}

This paper aims to investigate which ICTs should be used to affect the provision and quality of services provided and to facilitate efficient resource utilization within the local government unit. The following essential questions are addressed: 
- How is the government approaching ICTs and ICT policy regarding local government units?

- Which kind of ICT solutions are used in local government units?

- Which problems arise during the implementation and use of ICT in a local government unit?

- Which model of ICT system should be developed in local government units in Poland?

\section{Methodology}

An explorative and interpretative case study method was chosen to carry out this research. Scholz and Tietje (Scholz \& Olaf Tietje, 2013) have suggested that a case study is an appropriate method to develop a theory that aims at explaining how things are and why things are as they are according to our research question. Moreover, the case study research, through reports of past studies, allows the exploration and understanding of complex issues. It can be considered a robust research method, particularly when a holistic and in-depth investigation is required. A case study is recognized as an appropriate tool in many social sciences (Zaidah Zainal, 2007).

The data was collected using qualitative semi-structured interviews with authorities and IT specialists directly responsible for implementation of ICT in local government units. The local government unit in Polkowice has been presented as a typical case due to the full access to all information necessary to carry out this research. This analysis is supplemented by interviews with IT specialists, both within and outside the local government units, to understand how the ICT solutions are used and implemented in these institutions.

As mentioned above, the study was based mainly on a critical analysis of literature and interviews with managers and experts in ICT and BI areas. The results of this study can be used by IT and business leaders as they plan and develop in local government units.

\section{ICT Policy Regarding Local Government Units}

This section provides a general overview of concepts that include ICT systems, decision-making processes and e-government. The scope and focus of the thesis, as well as a role of the Programme for Computerization of the Polkowice Commune for 2008-2014 (PIG 2008-2014) is investigated. Moreover, a description of the ICT solutions in use in local government units in Polkowice is included. The region is a unit, which organizes the community at the multidistrict level. At the moment in Poland, there are 16 regions defined. Regions are not responsible for controlling or supervising districts and municipalities. They handle issues on a regional scale and are unregistered by the central government.

The scope of activities for the municipality is not legally defined, which means there is no limited range of tasks. The main task is to implement local and specific statutory public affairs and to perform other tasks not transferred by the programme to any other entity.

According to The Strategy of Sustainable Development dedicated to the public sector, authorities of particular public units were forced to focus on complex management. Through comprehensive analyses carried out over the last approximate ten years by the Municipal Council of Polkowice, it became possible to present its weakest point - strategic management. The Polkowice Commune requires handling a range of various planning documents of both a long-term, as well as shortterm character. Providing a well-organized data flow system in the Polkowice Commune is extremely important, due to its dynamically developing economy and growth, based mainly on exploitation of minerals and a range of activities increasing the quality of citizen life standard (Strategia rozwoju Gminy Polkowice, 2014). 
Local government units are local or regional local-governing communities. These units are selfcontained and autonomous in operation in the sphere of public affairs of local importance. They can differ in different countries. The characteristics below depict the situation in Poland (Infor, 2014).

Local government units operate through their constitutive organs. Each of the units provides a statutory constitutive, executive and control organ (Fig. 2).

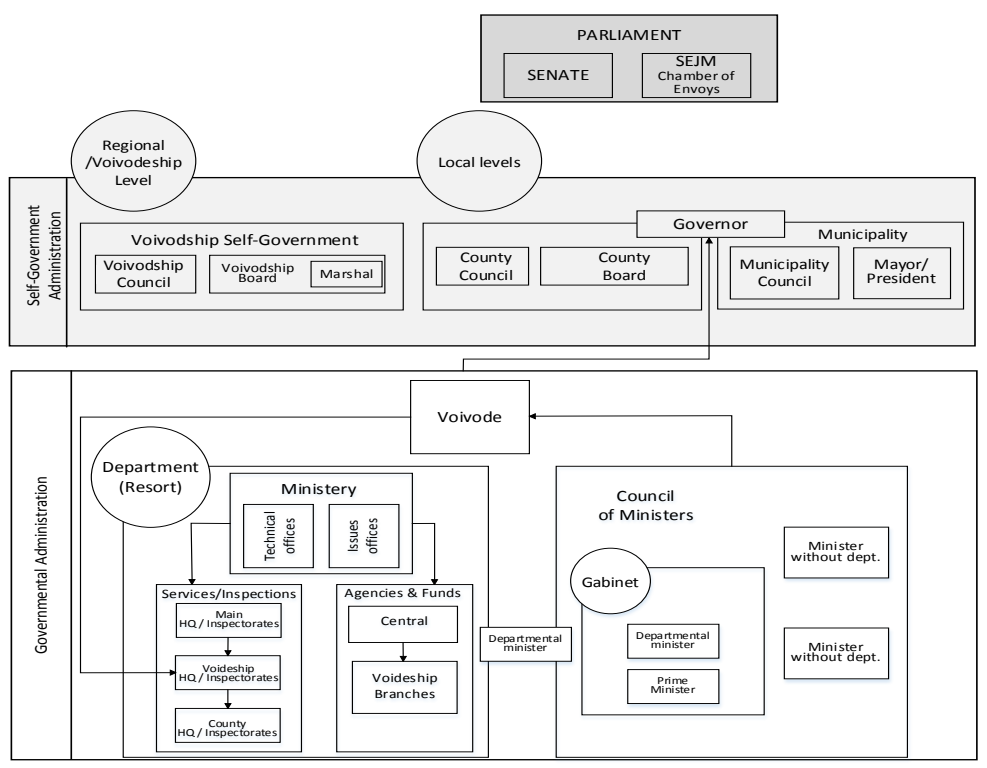

Figure 2. The public administration system in Poland

Source: based on Władze województwa, 2014

These units conduct their business in their own name and on their own responsibility. This means that each unit, within its field of competence, defines the objectives and their implementation, and is responsible for execution of these tasks (MSWIA, 2014).

The constitutive organs of municipalities are: the municipal council, which has competence in forming, control and depending on the size of the municipality, commune administrator, mayor or city president, who has executive authority. The constitutive organs of the district are the district council and board of the district, with a governor as a chairman. The constitutive organs of a region (province) are a council and the board chaired by the marshal of the region.

Activities in the field of computerization are included in the Strategy for Sustainable Development of the Polkowice Commune for 2008-2014. It is a document of crucial importance for the development of the Polkowice Commune. It contains a hierarchical structure of goals and objectives, the implementation of which will mean the correct evolution of economic, social and environmental areas. It is assumed that the actions undertaken according to the strategy will result not only in improving the quality of meeting the needs of the local community, but they will also generate funds to its budget, which is the budget of households and firms operating locally. This document also includes issues relating to the use of ICT to support decision-making processes. Below, some elements of the strategy for computerization are presented.

Development and implementation of the Programme for Computerization of the Polkowice Commune for 2008-2014 [PIG 2008-2014] includes:

- improvement of electronic delivery and record systems: property, contracts, invoices, HR, payroll, resolutions, orders, decisions, planning documents, contracts, land, build- 
ings, structures, technical infrastructure, premises, technical equipment and population processes

- construction of electronic analytical systems supporting decision-making processes by community authorities and management of organizational units of the community

- construction of electronic registration systems, circulation and archiving documents, as well as execution of tasks

- construction of Polkowice Information System (PSIP)

- construction of Electronic System of Administrative Services of the Polkowice Commune (ESUAP)

- the creation of a tourist, recreational and cultural online information portal

- the number and name of the operational or strategic task

In the case of the task of building electronic systems for analytical support for decision-making processes by the community authorities and the management of organizational units of the community, the following parameters were assigned: Period A-B, Rank G and the role of WFJ.

\section{Period A-B}

It consists of tasks that should start in the years 2008-2010 (the previous term of the local government), and whose completion should take place in the years of 2011-2014 (the current term of the local government), the tasks that have been started, and the outcome of which should be seen in 2011-2014 (the current term of the local government).

\section{Rank G}

It consists of tasks of major significance for the achievement of the strategic economic and or social and/or environmental objectives of the Polkowice Commune, which should be given special attention and involvement of local authorities.

\section{The role of WFJ}

It consists of strategic tasks that are partially the fulfillment of statutory duties (own) and partially optional tasks realized by the Polkowice Commune, which will play the major role (Uchwała Rady Miejskiej w Polkowicach, 2007).

The implementation of the tasks is related to computerization in all units of the Polkowice Commune, i.e.: Municipal Police, Community Centre, Primary Schools Number 1,2,3, Secondary Schools Number 1,2, a nursery, Social Welfare Centre, Polkowice Animation Centre, kindergartens, public utility company, Rural Cultural Centre in Sobin.

\section{ICT Solutions in a Government Public Unit}

Government and public sector organizations have many unique requirements that differentiate them from non-governmental organizations (NGOs) and must be addressed to their ERP systems. It is necessary to highlight the policy of computerization and three fields should be taken into account: information, software systems and infrastructure (Fig. 3). 


\section{Information}
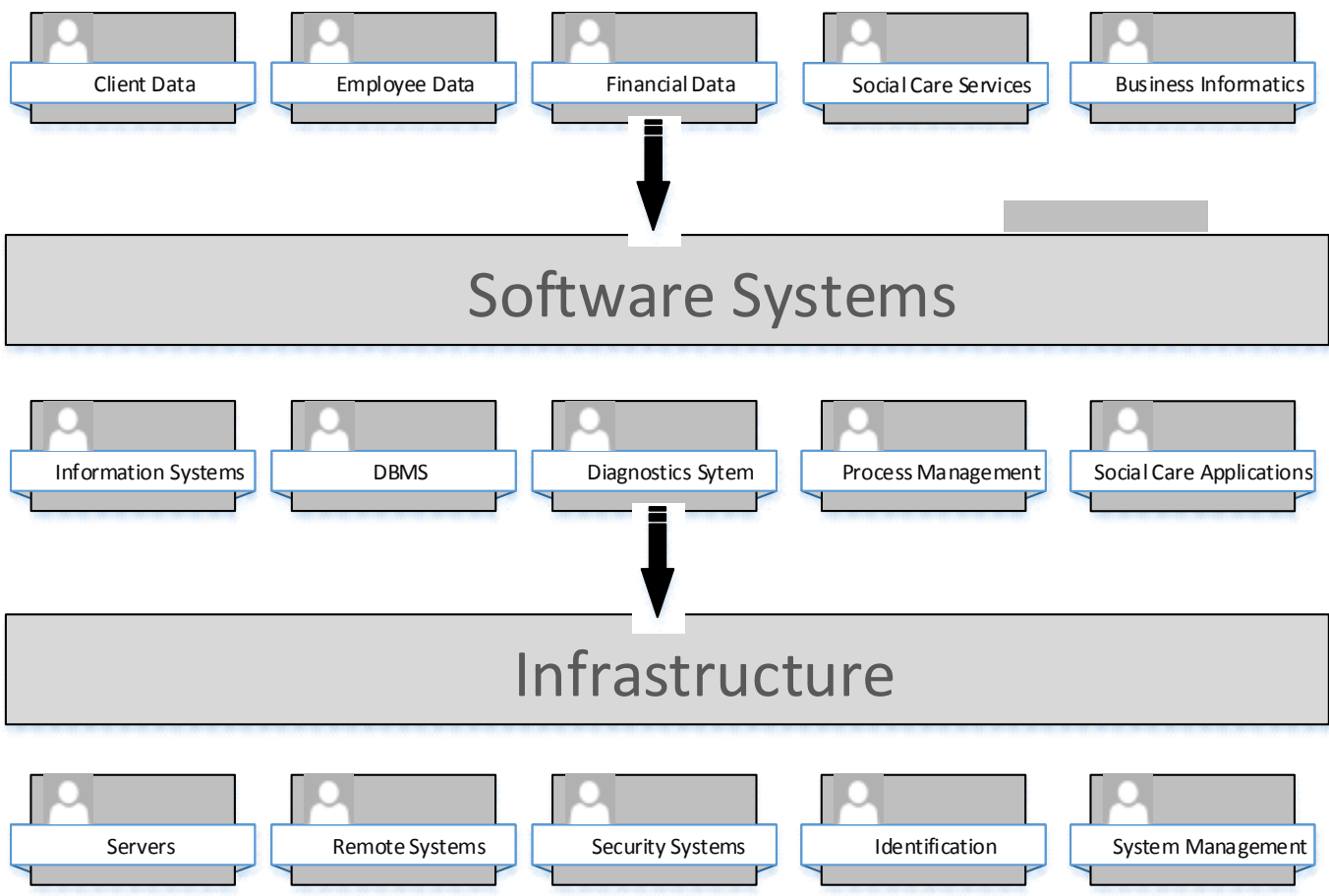

Figure 3. IT in a local government unit

Source: Author's own, based on: DeNardis L., ITU-T Technology Watch Report, 2011

Financials, procurement, tax and revenue management, customer and stakeholder portals, and full system integration are all key requirements. In addition, ERP solutions augment traditional ERP offerings with many specific functions, including compliance, security and fiscal accountability.

For this reason, applying systems in units of the Polkowice Commune is in accordance with the strategy developed by the SIGID system. Due to specific activities, some differences arise in individual local government units. For instance, the Department of Social Policy recommends the programs for social welfare (OU POMOST, POMOST STD, TT-POMOC, OPIEKA/RODZINY ZASTĘPCZE, HELIOS - POMOC SPOŁECZNA).

Other specialized systems like POMOST, SR (Świadczenia Rodzinne) and Statistical Central Application in the Community Centre are used. It is worth emphasizing that all local government units in Polkowice use the PlanB and SJO BeSTi@ systems, which have been implemented in OPS and officers use to collect and process information about clients of the institution. The data obtained in this way allow for optimal use of resources. The following paragraphs present the characteristics of the selected systems in units of the Polkowice Commune.

Below, selected systems that can support decision-making in local government units are characterized.

\section{The PlanB system - WPF}

The Public Finance Act of August 27, 2009, introduced the so-called Multiannual Financial Forecasts (WPF), which is a new mechanism for public financial management that has improved the rationality of management of public funds and increases transparency in the fiscal policy. 
The introduction of WPF in practice requires maintaining two parallel budgets in one- and multiyear budgets. The DOSKOMP Company developed the PlanB system "WPF", which aims to assist officers in local government units in preparing the one- and multi-year budgets. Moreover, it helps in managing the changes in both budgets.

The PlanB WPF is designed for local government units, including the city, municipal and district governor's offices, as well as organizational units that are required to draw up plans for spending and revenue.

The PlanB WPF has been successfully implemented in many local government units. Some of the biggest projects are in the cities of Gdynia, Czestochowa, Piotrkow and Trybunalski.

The system includes a set of issues related to budgeting in local governments and agencies, ranging from construction of the project budget, through the budget, amendments to the budget, the Multi-annual Financial Forecast, creating schedules and demands for cash, up to complex multidimensional analyses of budget implementation.

The PlanB system enables implementation of the following tasks:

- draft budget

- long-term financial forecast

- changes of the budget

- task budget (optional)

- requests for a change in the plan with the justification

- attachments to budget resolutions

- records of requests for cash and scheduling

- transmission of basic attachments to the SJO BeSTi@ system (Sputnik, 2014)

- implementation of the budget

The system should operate in each organizational unit.

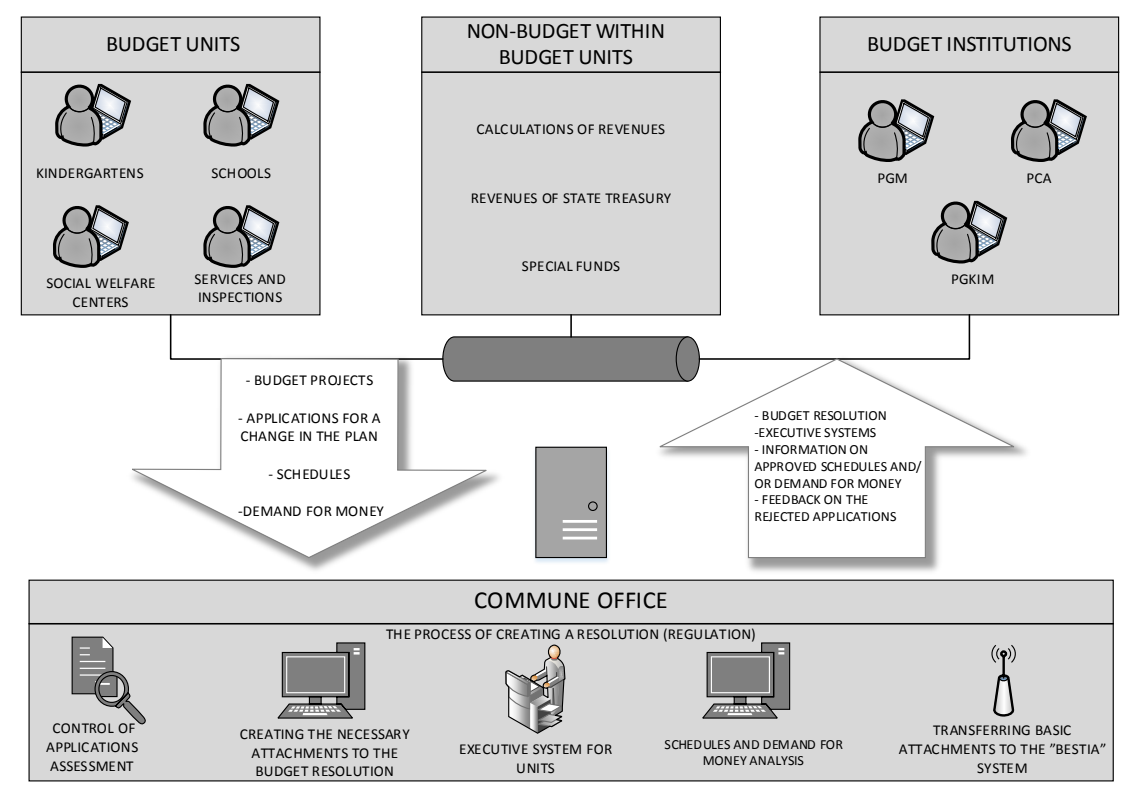

Figure 4. Model of the PlanB system (Source: own elaboration)

Where: PGM- the Enterprise of the Municipal Economy, PCA- the Centre of the Animation In Polkowice, PGKiM - the Enterprise of municipal services and housing 
The PlanB WPF works with the SJO BeSTi @ system for transmission of the required attachments to the budget resolution.

\section{The SJO BeSTi @ system}

The SJOBeSTi@ program is used to improve the financial management of local government units. It aims to help officers in implementation of the following tasks:

- planning the budget from the preparatory stage through all its changes

- creating monthly and quarterly reports

- drawing up the balance of local government units

- drawing up the total balance, including data from the balance of local government units (SJO

BeSTi@, 2014)

It is noted that each government unit is required to complete descriptive reports made in an Excel spreadsheet form by 30 June and 31 December. All documents must be signed with an electronic signature.

\section{The Pomost, Utility Software (OU POMOST)}

This application supports and facilitates services for social welfare beneficiaries. Among other things, the software supports processes of aid granting and aid distribution. The Pomost is a computer system designed for offices of social welfare centers and supports them in carrying out the tasks of the municipality and county, under the Social Assistance Act and associated legislation. The main task of the software is to support the decision-making process [7]. The system improves information flow, provides information for managers, controls the use of resources and forecasts needs. The system can gather records concerning families and issued documents, examine issues related to interviews, supports the decision-making process (grants, implementation and change benefits, evasion of interviews, request for reimbursement, appeals, etc.), accounting calculates referral service salaries for family subsidies and supports the process of preparing the reports. The software supports the activities of more than two thousand social welfare centers in Poland.

\section{Statistical Central Application (SAC)}

Central Statistical Application (SAC), the maintenance of which is one of the elements of the concluded agreement, enables all social welfare centers to efficiently transfer necessary information and data to the Ministry of Labour and Social Policy. Thanks to the application, employees of the ministry are able to verify data and reach any information submitted by any of the nearly three thousand social welfare centers. The system makes optimization of financial asset management possible, so as to direct aid to people who are the most in need. It is worth mentioning that KSMPS (National Social Welfare Monitoring System), serviced by SAC applications, gathers information enabling effective fraud detection in applying and granting social welfare (Sygnity, 2014).

OU POMOST and Central Statistical Application are parts of a wide range of Sygnity Group products for the social welfare sector. Its key elements are the system for family grant service, maintenance advance payment (which is supposed to be substituted by the maintenance fund), school grants and housing allowance. All of these products are bound together with electronic document circulation, together with Electronic Passing Box and the Local Government Information Platform. The OU POMOST system was developed in 1995-1999 within a framework of a project titled Automation of the Labour and Social Welfare Organisation and financed with World Bank funds. 
It also seems important to consider the possibility of providing municipal authorities of Polkowice with information on the functioning of single Polkowice Commune companies. In this case, a large autonomy of these companies may be observed, resulting from the nature of the business. For this reason, these entities in operation systems are inconsistent with the systems listed above. Moreover, in many cases the systems are not only ERP systems but a set of different modules from various systems. This situation creates problems not only for information decision-making at the level of the municipal authorities, but also in the companies. For this reason, the idea of integration of all of these systems has arisen to integrate the systems and to implement the business intelligence solutions to enable the supervisory board of these companies to be supported in managerial decisions by the results of the complex and multidimensional analyses.

The Single Board Municipalities in Polkowice with 100\% participation are:

- Aquapark Polkowice Regionalne Centrum Rekreacyjno-Rehabilitacyjne S.A. (Profin., Stream Soft, LSI)

- Klub Sportowy Polkowice Sp. z o. o. (Subiekt, Magic)

- Polkowickie Towarzystwo Budownictwa Społecznego Sp. z o.o. (integrated ERP Unisoft)

- Przedsiębiorstwo Gospodarki Miejskiej Sp. z o.o. (the ERP system of Unisoft currently implemented)

Although the authorities of Polkowice consistently implement the Sustainable Development Strategy for Polkowice, adopted on 27 December 2007, there is a lack of use of business intelligence tools. The analysis, as well as meetings of scientists from the University of Economics and DWSPiT (Dolnoślaska Wyższa Szkoła Przedsiębiorczości i Techniki), illustrate their activities in the field aimed at exploring the possibility of their use, as well as to determine the resulting benefits.

On this basis, the research team will examine the possibilities, as well as conditions, for how to implement, use the BI tools and finally improve the decision-making process of the Polkowice Commune.

The authors' intention is to present a proposal of application of BI tools to support the process of decision making at the management level. It is assumed that the integration of information systems, as well as the use of BI solutions, will help to solve many problems in decision-making.

\section{ePUAP}

Electronic Platform of Public Administration Services (ePUAP) is a coherent and systematic action program designed and developed to allow public institutions to make their electronic services available to the public. The website www.epuap.gov.pl enables defining citizen and businesses service processes, creates channels of access to different systems of public administration and extends the package of public services provided electronically (http://epuap.gov.pl/wps/portal/)

\section{Płatnik and Przekaz Elektroniczny ZUS}

Płatnik is a computer program created by Asseco Poland SA that is used for sending insurance documents to the Social Insurance Institution (ZUS) in electronic form by individuals and companies who have such an obligation. The program is free of charge, but only works under MS Windows.

Among other functions, Płatnik offers preparation of insurance documents and their review, and the printing of documents. After obtaining the public key, a certificate can be transmitted electronically to the ZUS documents via electronic transmission or on physical media (CDs). In addition, the Płatnik provides data import from payroll systems, the maintenance of historical data of 
insured persons, prints bank transfers and payment documents and prepares bank transfers in the form of a text file.

\section{e-deklaracje}

E-deklaracje is part of the e-Podatki system and is available through

www.portalpodatkowy.mf.gov.pl. E-deklaracje was adopted at the end of July 2014 and has since processed over 58 million documents in electronic form. The Ministry of Finance encourages the settlement of tax administration in electronic form

\section{Results}

The research results show, although there are various interesting and innovative ICT projects carried out by the Ministry of Social Policy and other NGOs, a kind of chaos can be noticed. There is lack of principal rules necessary in the field of computerizing, as well as when recognizing the role of the Internet in particular units. It is surely a result of incomplete coordination of IT actions between local government units and governmental units. On one hand, there are innovative projects being implemented, on the other, managers and IT specialists have problems to implement it because of lack of support from outside institutions. The solution to this "resonance" might be the introduction of standard and unified IT elements used in local government units. A similar situation exists in other public institutions, such as schools and offices. Despite this, there are regulations related to the use of IT systems and data safety, with the level of computerizing depending vastly on human resources (IT specialists), equipment and software, as well as the open-mind of decision makers towards the innovation.

Therefore, development and implementation of the hybrid solution might turn out to be the most convenient. This solution combines elements like species, types, structures and methods into an integrated whole. The result of the merger reveals a synergistic effect of hybrids that demonstrates the qualities that are hard to watch in the original ingredients. The unique properties of the hybrids mean that in many disciplines, working on such systems can be considered as one of the most promising research directions (Radosiński 2001).

In the model of the hybrid information system in Figure 5, the role of the business intelligence systems should be especially highlighted, due to the fact it integrates all systems and, based on their data required by the commune authorities, analysis should be realized to support the decision-making processes. 


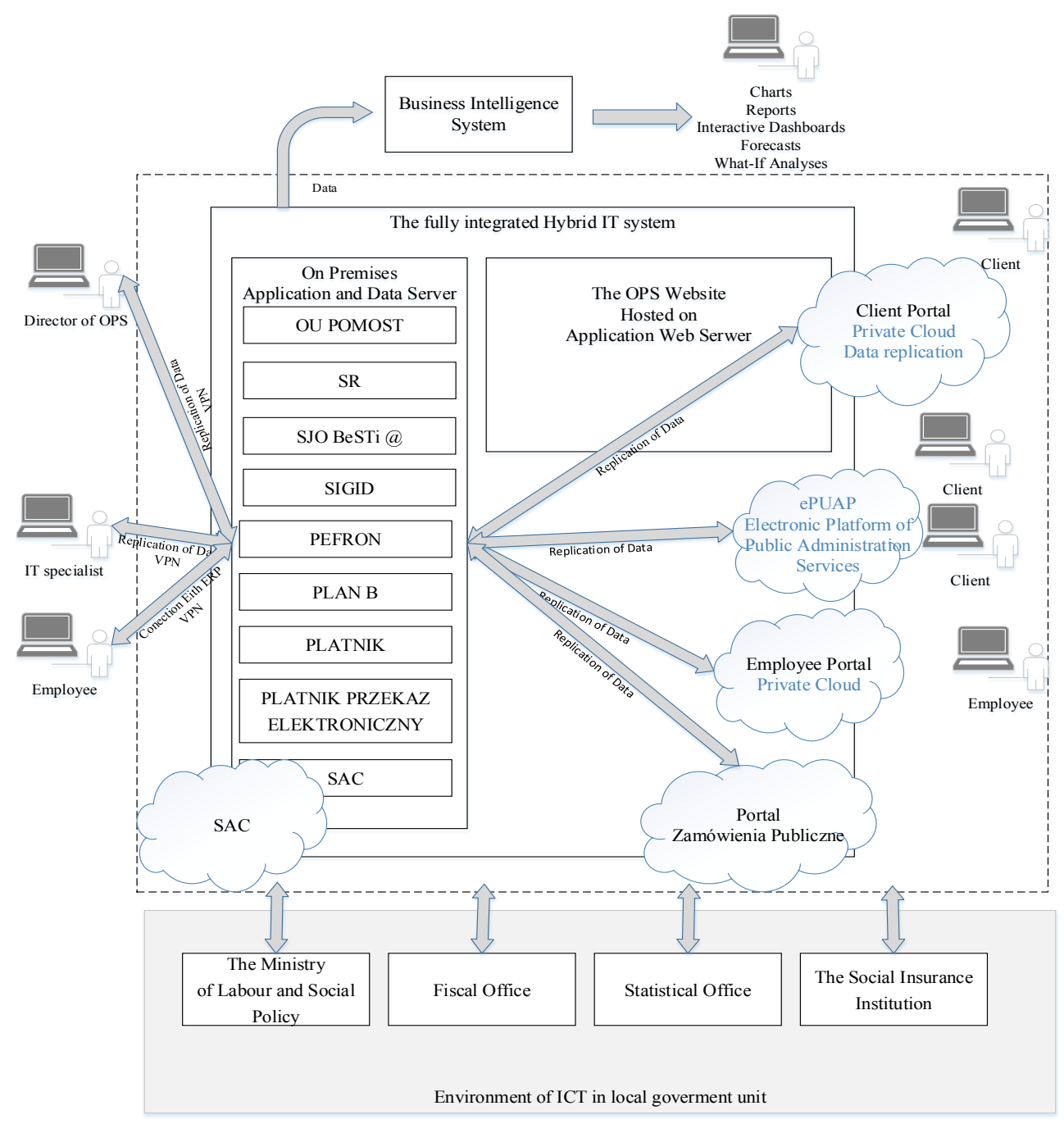

Figure. 5. Model of the hybrid information system in the local government unit. Example of the OPS Polkowice. Source: own elaboration

\section{Conclusions}

This paper may be useful both for researchers as well as for managers and IT specialists. As earlier mentioned, in Poland there are few publications in this field. The lack of publication is primarily due to difficult access to the data. In addition, Poland is still lacking regarding close cooperation between academic institutions and companies. The lack of penetration of theory and practice is visible. In the case of this paper, it was possible to eliminate this inconvenience because the authors are both professors and responsible for the implementation of ICT solutions in a local government unit. Particularly noteworthy is the fact that the authors have accurately known a course of computerization in these institutions since 1991.

The proper implementation of ERP systems requires the use of structured methods and procedures for the implementation of different phases. In addition, current trends and the emergence of new solutions in this case must be taken into account. From the research that has been carried out, it is possible to conclude that the suggested model of a fully integrated ICT system can be used. 
The findings are of direct practical relevance. The research suggests that this approach could be useful for academics, as well.

\section{References}

Baxter, P., \& Jack S. (2008). Qualitative case study methodology: Study design and implementation for novice researchers. The Qualitative Report, 13(4), 544-559. Retrieved May 17, 2014 from http://www.nova.edu/ssss/QR/QR13-4/baxter.pdf

BI System. (2003). Technologia czy kultura. Computerworld, Strategie, February.

Business Intelligence for Public Sector Government. (2014). MAIA Intelligence. Retrieved June 12, 2014 from http://www.maia-intelligence.com/pdf/1KEY-Agile-BI-Suite-for-Public-Sector-Government.pdf

DOSKOMP. (2014). Serwis jst.pl. Retrieved May 15, 2014 from http://www.doskomp.jst.pl

ePUAP. (2014). What is ePUAP? Retrieved May 15, 2014 from http://epuap.gov.pl/wps/portal/!ut/p/a1/hY6xDoIwFEW xrXvUQriiImDLAwSi28xJakFLRSR2N3JK7i3W5ybu4BghpoUO OqLlzg7JLp Qa7biIAmL8iASPJ6rgmfblKPgAbgEAH8kx397CbSK1PEXWLkogIx1TdCVe6Cqt88NmsUsH5o4M0CTvulJ T6x1rxlq7z0zzhmr2Whh7Gu8Jw_5AbUYcPI!/dl5/d5/L2dJQSEvUUt3QS80SmlFL1o2XzE5MjQxMl MwSk9FNDUwSVZUSjI4NzYyMFMx/?lang=en

Himanshu Tiwari. (2014). Data mining, warehousing and OLAP technology. Discovery, 24(83).

Infor. (2014). Retrieved May 23, 2014 from http://www.infor.pl/prawo/encyklopediaprawa/j/273389,Jednostka-samorzadu-terytorialnego.html

Instrukcja użytkowania systemu SJO BeSTi@. (2014). Retrieved May 16, 2014 from http://pomoc.sputniksoftware.com/pliki/instalki/Bestia/SJODokumentacjaUzytkownika.pdf

Kaminska, T. (2010). The information society in Poland - The individuals' approach. International Journal of Emerging and Transition Economies, 3(2), 269-284.

MSWIA. (2014). Retrieved June 12, 2014 from http://www.mswia.gov.pl/portal/pl/321/4328/Administracja_publiczna.html

Nycz M. (2007). Pozyskiwanie wiedzy menedżerskiej. Podejście technologiczne. Wydawnictwa Akademii Ekonomicznej im. O. Langego we Wrocławiu, Wrocław 2007

Nycz, M., \& Pólkowski, Z. (2014a). The methodology of implementing the ERP system in a municipal enterprise. International Conference on Information Technologies in Business and Education, Varna 2014.

Nycz, M., \& Pólkowski, Z. (2014b). The modern ICT solutions in the fully integrated hybrid information system in the Municipal Services Enterprise. International Conference on Information Technologies in Business and Education, Varna, 2014

Powiat polkowicki. (2014). Retrieved April 20, 2014 from http://www.zgzm.pl/nasze-gminy/gminapolkowice/

Radosiński, E. (2013). Systemy informatyczne w dynamicznej analizie decyzyjnej. PWN, Warszawa.

Sauer, A. (2013). The system of the local self-governments in Poland. Association for International Affairs, December.

Sputnik. (2014). Retrieved June 10, 2014 from http://pomoc.sputniksoftware.com/pliki/instalki/Bestia/SJODokumentacjaUzytkownika.pdf

SR, FA, ST, DM. (2014). Retrieved May 16, 2014 from http://public.sygnity.pl/zabezpieczeniespoleczne/sr-fa-st-dm/osystemie 
Strategia Rozwoju Zrównoważonego Gminy Polkowice na lata 2010-2015. (2014). Retrieved May 16, 2014 from http://www.bip.ug.polkowice.pl/183,Strategia-Rozwoju-Zrownowazonego-GminyPolkowice-na-lata-2010-2015.html

Sustainable Development Indicators for Poland. (2011). Central Statistical Office, Katowice.

Świętokrzyski Urząd Wojewódzki w Kielcach. (2014). Jakie zadania realizują Systemy Informatyczne w obszarze pomocy spolecznej ? Retrieved April 15, 2014 from http://www.kielce.uw.gov.pl/pl/urzad/polityka-spoleczna/systemy-informatyczne-u/jakie-zadaniarealizuja/115,Jakie-zadania-realizuja-Systemy-Informatyczne-w-obszarze-pomocy-spolecznej.html

Sygnity. (2014). Retrieved April 20, 2014 from http://public.sygnity.pl/zabezpieczenie-spoleczne/sr-fa-stdm/osystemie

Uchwała Nr XII/126/07 Rady Miejskiej w Polkowicach. (2007). Retrieved May 12, 2014 from http://www.bip.polkowice.eu/doc/strategia.pdf

Uppatumwichian, W., Johansson, B., \& Carlsson, S. (2011, July). Accounting Solutions Use for Budgeting in ERP, Hybrid ERP And BoB: An Explorative Study. In Proceedings of PACIS (p. 196).

Vasilev J. The change from ERP II to ERP III systems. Sofia, 2013, pp 382

Władze Województwa. (2014). Retrieved May 10, 2014 from http://www.lubelskie.pl/index.php?pid=400

Zaidah Zainal. (2007). Case study as a research method, Jurnal Kemanusiaan bil.9, June.

\section{Biography}

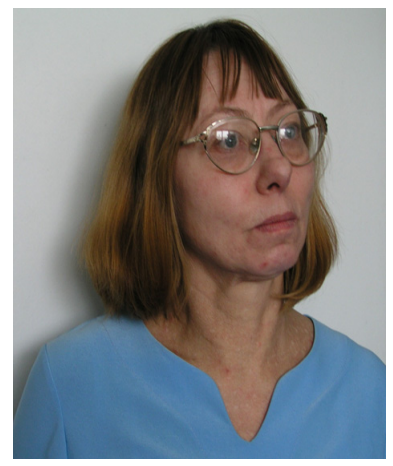

Professor Malgorzata Nycz, PhD, is an associate professor at the department of Artificial Intelligence Systems of Wrocław University. She has authored many publications, mainly oriented on intelligent system topics, business intelligence, data warehouses and distance learning issues. Her current research is in intelligent systems with a focus on knowledge discovery from databases and modern education including e- learning processes. Prof. Nycz runs classes in subjects such as computer science, databases, basic artificial intelligence, data warehousing, business intelligence management and business intelligence across an enterprise.

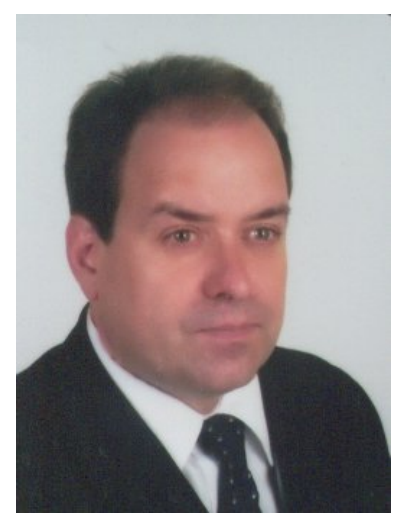

Dr. Zdzisław Pólkowski, PhD, is an assistant professor at the Department of Technology at The Lower Silesian University of Entrepreneurship and Technology (DWSPiT) in Polkowice, Poland. He runs classes within the fields of business informatics, e-administration and IT. He conducts research in such business informatics as e-business, ecommerce, IT systems in business and ERP systems. Dr. Pólkowski maintains contacts with numerous academics in Poland and abroad. Moreover, he is the owner of a small company, where he tries and tests new ideas in practice. In Polkowice, he has carried out many IT projects, especially in schools, small companies and government institutions. Contact with other small companies allows him to define the upto-date state of using IT tools in business. Website:

www.studenci.polkowski.com.pl. 